Document downloaded from:

http://hdl.handle.net/10251/168229

This paper must be cited as:

Sanchez, O.; Castañeda, K.; Mejía, G.; Pellicer, E. (2020). Delay Factors: A Comparative Analysis between Road Infrastructure and Building Projects. American Society of Civil Engineers. 223-231. https://doi.org/10.1061/9780784482889.024

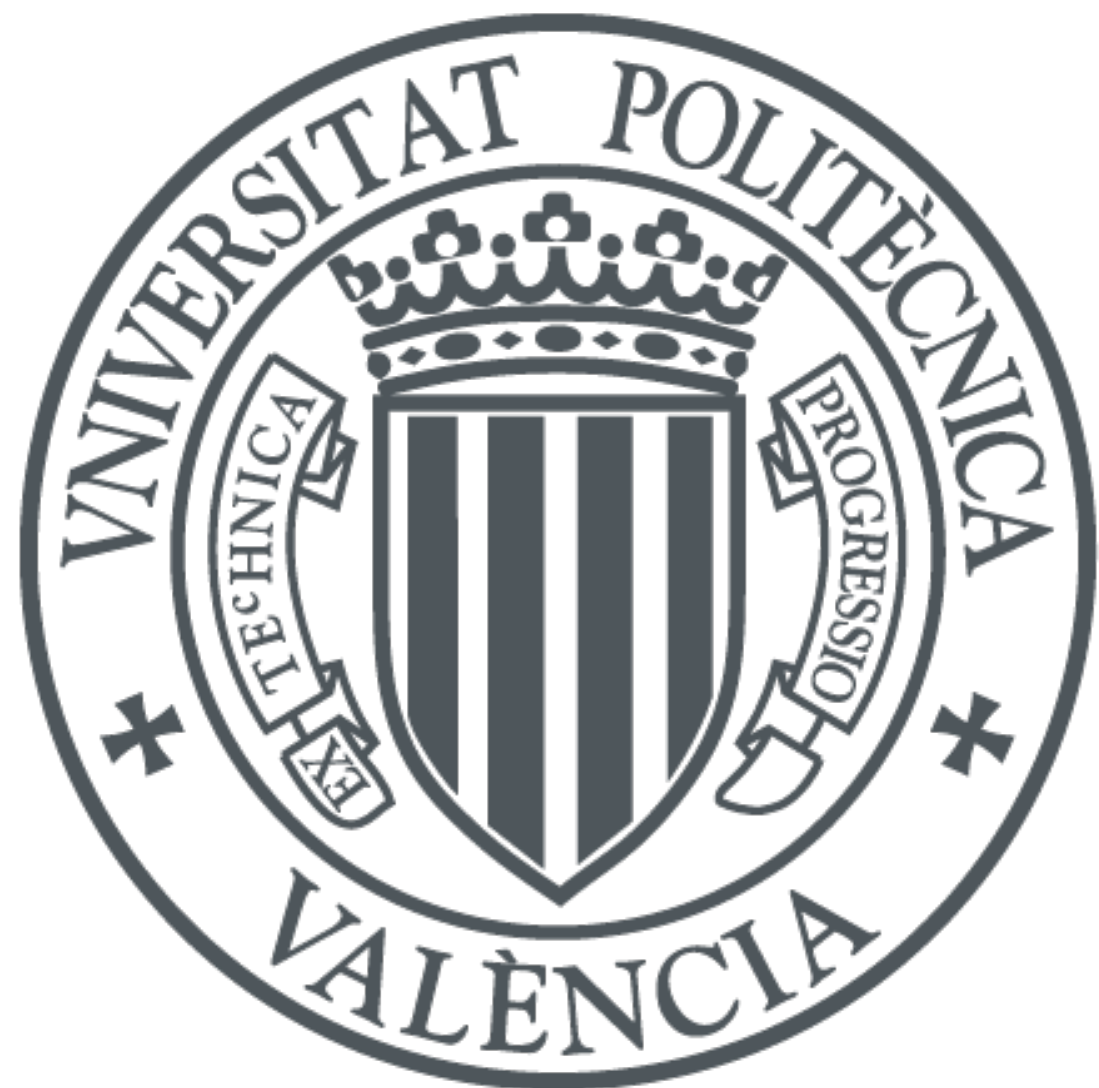

The final publication is available at

https://doi.org/10.1061/9780784482889.024

Copyright American Society of Civil Engineers

Additional Information

This material may be downloaded for personal use only. Any other use requires prior permission of the American Society of Civil Engineers. This material may be found at https://doi.org/10.1061/9780784482889.024 


\title{
Delay Factors: A Comparative Analysis between Road Infrastructure and Building Projects
}

\author{
Omar SÁNCHEZ ${ }^{1}$; Karen CASTAÑEDA ${ }^{2}$; Guillermo MEJÍA ${ }^{3}$ and Eugenio \\ PELLICER $^{4}$
}

${ }^{1} \mathrm{Ph}$. D. Candidate, Civil Engineering Department, Universidad Industrial de Santander, P.O. Box 680002, Bucaramanga, Santander, Colombia, (57+7) 63440002486; FAX (57+7) 6320744-2486; email: omar.sanchez@correo.uis.edu.co

${ }^{2}$ M. Sc. Candidate, Civil Engineering Department, Universidad Industrial de Santander, P.O. Box 680002, Bucaramanga, Santander, Colombia, (57+7) 63440002485; FAX (57+7) 6320744-2486; email: karencasta.ing@outlook.es

${ }^{3}$ Professor, Civil Engineering Department, Universidad Industrial de Santander, P.O. Box 680002, Bucaramanga, Santander, Colombia, (57+7) 6344000-1301; FAX (57+7) 6320744-2486; email: gmejia@uis.edu.co

${ }^{4}$ Professor, School of Civil Engineering, Universitat Politècnica de València, Camino de Vera, s/n, 46022 Valencia, Spain, (34) 963879562; FAX (34) 963877569; email: pellicer@upv.es

\section{ABSTRACT}

Delay is one of the most common, complex and risky phenomena that adversely affects performance of construction projects. Several studies have been conducted on delay factors identification, some focused on road infrastructures, others on buildings, or on construction projects broadly. However, there are scarce publications with a comprehensive and sound analysis among projects of different type. This study presents a comparative analysis of delay factors between road infrastructure and building projects using the following research process: (1) a systematic review of articles published in specialized and peer-reviewed journals is performed; 2) relevant studies are chosen based on inclusion/exclusion criteria; (3) qualitative evidence is categorized; (4) quantitative evidence is analyzed with Spearman's Rank Correlation Coefficient; and (5) contributions are summarized. A final set of twenty published articles provided quantitative and qualitative evidence of construction delays. The findings indicated that delay factors identification and prioritization differs between projects and countries. Some critical delay factors for road infrastructure projects were inadequate contractor's experience and payment delays to contractor, while for building projects were shortage of materials and financial difficulties of contractor.

\section{INTRODUCTION}

In the construction industry, concluding projects on time, within budget and according to the specifications are indicators of success, efficiency and an adequate management (Singh et al. 2018; Abdellatif and Alshibani 2019). However, the construction process is affected by unpredictable variables and events (Patil, Gupta, Desa, \& Sajane, 2013), which may cause time and cost overruns. A time overrun is a phenomenon known as delay in construction projects (Kaming et al. 1997; Durdyev, 
Omarov, and Ismail 2017). Every construction project is exposed to delays for many reasons and factors, with critical consequences that differ from one project to another (Alaghbari et al. 2007; Santoso and Soeng 2016), and from one country to another (Singh et al., 2018). The main consequences of delays in construction projects are (Aibinu and Odeyinka 2006; Mahamid 2017b): cost overrun, disputes, arbitration, litigation, and poor quality.

Despite of its importance, the problem of delays in construction projects has remained over time in both developing and advanced economies (Amoatey, Ameyaw, Adaku, \& Famiyeh, 2015), being a priority issue for years (Honrao \& Desai, 2015). Some evidences of delays in construction are detailed next. Aibinu and Odeyinka (2006) studied 60 building projects in Nigeria, finding an average delay of $90 \%$ in residential projects and 63\% in office projects. Mahamid (2017a) analyzed 101 road projects in Palestine and determined an average delay of $48 \%$. Al-Hazim, Salem, and Ahmad (2017) examined 14 construction projects in Jordan where found delays ranges from $125 \%$ to $455 \%$ with an average of $226 \%$.

Although delays occur in both road and building projects (Mahamid, 2017a), the influencing factors differ according to the type of project. While road projects are undertaken by horizontal construction processes, building projects are undertaken by vertical construction processes. Thus, road projects are more mechanized, with construction works exposed to the weather effects (Durdyev et al., 2017), requiring more earth movement activities, and involving a greater extension of land, compared to building projects. By the contrary, building projects are more exposed to clashes between elements and have a greater risk to be affected by problems of space at the construction site, in comparison to road projects. Furthermore, in building projects, the construction activities are highly dependent on each other, so that a delay in an activity can lead to a delay in several activities; on the contrary, the linear nature of road projects provides greater flexibility to construction schedule. Finally, regarding project funding, road projects are usually public projects, whereas building projects could be public or private (Omoregie \& Radford, 2006).

Delay in construction industry has been attracting attention of researchers and practitioners for decades (Durdyev et al., 2017); in fact, a lot of studies of delay factors have been undertaken in different countries (Akogbe, Feng, and Zhou 2013; Singh et al. 2018; Abdellatif and Alshibani 2019). The majority of them focus on construction projects, in a broad sense, and not on a determined type of project. Besides a small number of studies are focused only either on road or building projects, there is scarce comparative studies between these two kinds of projects. Considering this gap, the aim of this study is to compare delay factors between road and building projects through: their frequency of report (qualitative analysis), their influence index, and Spearman's Rank Correlation Coefficient (quantitative analysis).

\section{RELEVANT STUDIES ON DELAY FACTORS}

The first step of this study was a search and selection of relevant studies. The search was made by Scopus and Web of Science databases: as a result, a total of 746 documents, initially were collected. Then, a selection process was undertaken under the following inclusion/exclusion criteria: 1) the document reports delay causes related to construction projects; 2) the document focuses only either on road projects 
or only on building projects; 3 ) the document report ranking of delay causes with top $10 ; 4)$ the sample is not repeated with other studies selected; and 5) the document was published in specialized and peer-reviewed journal. Finally, a sample of 20 documents provided the data for this study (see Table 1).

Table 1. Studies selected of delay factors by region, country and project type

\begin{tabular}{|c|c|c|c|c|}
\hline Region & Road & Country & Building & Country \\
\hline \multirow{5}{*}{ Africa } & $\begin{array}{l}\text { (Rachid, Toufik, \& } \\
\text { Mohammed, 2018) }\end{array}$ & Algeria & (Akogbe et al., 2013) & Benin \\
\hline & $\begin{array}{c}\text { (Aziz \& Abdel- } \\
\text { Hakam, 2016) }\end{array}$ & Egypt & $\begin{array}{l}\text { (El-Razek, Bassioni, } \\
\text { \& Mobarak, 2008) }\end{array}$ & Egypt \\
\hline & $\begin{array}{c}\text { (Amoatey \& Okanta, } \\
2017)\end{array}$ & Ghana & $\begin{array}{c}\text { (Amoatey et al., } \\
\text { 2015) }\end{array}$ & Ghana \\
\hline & $\begin{array}{l}\text { (Khair, Mohamed, } \\
\text { Mohammad, Farouk, } \\
\text { \& Ahmed, 2017) }\end{array}$ & Sudan & $\begin{array}{l}\text { (Famiyeh, Amoatey, } \\
\text { \& Adaku, 2017) }\end{array}$ & Ghana \\
\hline & $\begin{array}{c}\text { (Kaliba, Muya, \& } \\
\text { Mumba, 2009) }\end{array}$ & Zambia & $\begin{array}{c}\text { (Aibinu \& Odeyinka, } \\
2006)\end{array}$ & Nigeria \\
\hline \multirow{5}{*}{ Asia } & $\begin{array}{c}\text { (Santoso \& Soeng, } \\
2016)\end{array}$ & Cambodia & $\begin{array}{c}\text { (Durdyev et al., } \\
\text { 2017) }\end{array}$ & Cambodia \\
\hline & $\begin{array}{l}\text { (Venkateswaran \& } \\
\text { Murugasan, 2017) }\end{array}$ & India & (Singh et al., 2018) & India \\
\hline & $\begin{array}{c}\text { (Mahamid, Bruland, } \\
\text { \& Dmaidi, 2012) }\end{array}$ & Palestine & $\begin{array}{c}\text { (Kaming et al., } \\
\text { 1997) }\end{array}$ & Indonesia \\
\hline & (Mahamid, 2017a) & Palestine & $\begin{array}{c}\text { (Alaghbari et al., } \\
\text { 2007) }\end{array}$ & Malaysia \\
\hline & $\begin{array}{c}\text { (Sohu, Chandio, \& } \\
\text { Keleemullah, 2019) }\end{array}$ & Pakistan & $\begin{array}{c}\text { (Abdellatif \& } \\
\text { Alshibani, 2019) }\end{array}$ & $\begin{array}{l}\text { Saudi } \\
\text { Arabia }\end{array}$ \\
\hline
\end{tabular}

\section{QUALITATIVE EVIDENCE OF DELAY FACTORS}

The 10 most important delay factors reported by each study were selected, gathering a total of 200 delay factors. Next, these factors were grouped by similarity into 41 different delay factors (See Table 2). In road projects the delay factor with a higher frequency was "payment delays to contractor" while in building projects was "shortage of materials". Taking into consideration the frequencies shown in Table 2, there are notable differences in some delay factors:

1) "Shortage of materials" obtained a frequency of 12 in building projects while in road projects the frequency is 3 . This phenomenon could be related to the materials diversity and the reduced storage space in building projects, contrary to road projects, where materials diversity is lower and storage space is greater.

2) "Inadequate project planning", for buildings the frequency is 10 while in roads is 5. It could be related to the fact that project planning in buildings involve a greater complexity and number of variables than road projects where planning involves linear methods with more flexibility in the face of unforeseen events. 
3) "Financial difficulties of contractor" for buildings the frequency is 7 while in roads is 2 . It could be due to that building projects can lead to a cash flow with a greater number of financial movements that can face the contractor to negative cash flows. This, added to the fact that the owners of building projects can be public or private entities, could increase uncertainty in payments to the contractor.

4) "Inadequate contractor's experience" for roads the frequency is 4 while in buildings is 1 . It could be related to the fact that in the construction industry of some countries the number of contractors with adequate experience in the road infrastructure sector is lower than the number of contractors with adequate experience in building projects. Therefore, in certain periods there could be shortages of contractors.

Table 2. Top 20 delay factors according to the frequency of report by the sample of studies

\begin{tabular}{|c|c|c|c|c|}
\hline Id & Delay factor & $\begin{array}{c}\text { Road } \\
\text { Frequency } \\
\end{array}$ & $\begin{array}{c}\text { Building } \\
\text { Frequency } \\
\end{array}$ & $\begin{array}{c}\text { Total } \\
\text { Frequency } \\
\end{array}$ \\
\hline F1 & Shortage of materials & 3 & 12 & 15 \\
\hline F2 & Inadequate project planning & 5 & 10 & 15 \\
\hline F3 & Financial difficulties of owner & 6 & 8 & 14 \\
\hline F4 & Payment delays to contractor & 8 & 5 & 13 \\
\hline F5 & Poor site management and supervision & 6 & 6 & 12 \\
\hline F6 & $\begin{array}{l}\text { Poor communication among } \\
\text { stakeholders }\end{array}$ & 4 & 5 & 9 \\
\hline F7 & Late decision making by owner & 4 & 5 & 9 \\
\hline F8 & Financial difficulties of contractor & 2 & 7 & 9 \\
\hline F9 & Shortage of equipment & 5 & 3 & 8 \\
\hline F10 & Failures in design & 2 & 5 & 7 \\
\hline F11 & Design changes & 3 & 4 & 7 \\
\hline F12 & Price variation of materials & 2 & 4 & 6 \\
\hline F13 & Low productivity of labor & 3 & 3 & 6 \\
\hline F14 & Inadequate contractor's experience & 4 & 1 & 5 \\
\hline F15 & Claims and disputes with stakeholders & 3 & 2 & 5 \\
\hline F16 & Shortage of labor & 1 & 3 & 4 \\
\hline F17 & $\begin{array}{l}\text { Late approval of shop drawings and } \\
\text { sample materials }\end{array}$ & 1 & 3 & 4 \\
\hline F18 & Delays of activities & 2 & 2 & 4 \\
\hline F19 & Poor site investigation & 2 & 1 & 3 \\
\hline F20 & Unrealistic contract duration & 2 & 1 & 3 \\
\hline
\end{tabular}

\section{QUANTITY EVIDENCE OF DELAY FACTORS}

The quantity analysis for the delay factors was made with the Influence Index (II) and the Spearman's rank correlation coefficient considering the ranks reported in each study of the sample selected. 


\section{Influence Index}

To obtain the influence index (II) for each delay factor the process started with the inverse rank (IR) that was calculated by the Equation 1, taking into consideration the rank reported (RR). For example, (Singh et al., 2018) reported "poor site management and supervision" with $R R=1$, thus, the $I R=10$.

$$
I R=10-(R R-1)
$$

Then, the Relative Important Index (RII) was obtained by the Equation 2, an adaptation of the RII used by: Amoatey and Okanta (2017) and Durdyev, Omarov, and Ismail (2017).

$$
R I I=\frac{\sum I R}{I R \max \times N}
$$

where: $I R$ is the inverse rank for each delay cause (obtained by the Equation 1); IRmax is the maximum IR value (IRmax $=10) ; N$ is the total number of primary studies of each type of project $(N=10)$. Finally, the influence index $(I I)$ was calculated according to the Equation 3, obtained through an adaptation of the important index used by Akogbe, Feng, and Zhou (2013), Rached, Toufik and Mohammed (2018), and Santoso Soeng (2016). Table 3 shows the top 20 delay factors with a greater influence index. The influence index was selected for the quantitative analysis considering that it involves the frequency and importance variables for each factor in a single index.

$$
I I=R I I x \text { frequency }(3)
$$

Analyzing the differences between the Influence Indices of road and building

projects ( $\left.I I_{\text {Building }}-I I_{\text {Road }}\right)$ and the differences of ranks $\left(R_{\text {Building }}-R_{\text {Road }}\right)$ reported in the Table 3, was possible to identify: delay factors with more influence on road projects (see Table 4), delay factors with more influence on building projects (see Table 5) and delay factors with similar influence on road and building projects (see Table 6).

\section{Spearman's rank correlation}

The Spearman's rank correlation coefficient (Equation 4) was used to analyze the correlation between the delay factors reported in road and building projects, which is a non-parametric test of statistical dependence between two variables. A perfect Spearman's correlation of \pm 1 occurs when each of the variables is a perfect monotone function of the other.

$$
\rho=1-\frac{6 \sum d^{2}}{n^{3}-n}
$$


Where: $\rho$ is the Spearman's rank correlation coefficient, $d$ is the difference between the ranks given by influence indices for an individual delay factor and $n$ is the number of delay factors (see Table 7).

Table 3. Top 20 delay factors according to the influence index

\begin{tabular}{|c|c|c|c|c|c|c|c|}
\hline \multirow{2}{*}{ Id } & \multirow{2}{*}{ Delay factor } & \multicolumn{2}{|c|}{ Road } & \multicolumn{2}{|c|}{ Building } & \multicolumn{2}{|c|}{ Overall } \\
\hline & & $I I_{R}$ & Rank & $I I_{B}$ & Rank & $I I_{O}$ & Rank \\
\hline F3 & Financial difficulties of owner & 2.88 & 2 & 4.96 & 3 & 7.70 & 1 \\
\hline F4 & Payment delays to contractor & 5.12 & 1 & 2.38 & 5 & 7.25 & 2 \\
\hline F1 & Shortage of materials & 0.48 & 11 & 8.34 & 1 & 6.41 & 3 \\
\hline F2 & Inadequate project planning & 0.98 & 6 & 5.30 & 2 & 5.44 & 4 \\
\hline F5 & $\begin{array}{l}\text { Poor site management and } \\
\text { supervision }\end{array}$ & 1.53 & 3 & 1.62 & 6 & 3.15 & 5 \\
\hline F8 & Financial difficulties of contractor & 0.18 & 25 & 3.71 & 4 & 2.79 & 6 \\
\hline F7 & Late decision making by owner & 0.76 & 9 & 1.03 & 8 & 1.78 & 7 \\
\hline F6 & $\begin{array}{l}\text { Poor communication among } \\
\text { stakeholders }\end{array}$ & 0.92 & 7 & 0.80 & 11 & 1.76 & 8 \\
\hline F9 & Shortage of equipment & 1.43 & 4 & 0.33 & 14 & 1.58 & 9 \\
\hline F10 & Failures in design & 0.22 & 21 & 1.35 & 7 & 1.33 & 10 \\
\hline F11 & Design changes & 0.21 & 23 & 0.96 & 9 & 1.09 & 11 \\
\hline F12 & Price variation of materials & 0.26 & 18 & 0.80 & 11 & 0.99 & 12 \\
\hline F13 & Low productivity of labor & 0.21 & 23 & 0.72 & 12 & 0.93 & 13 \\
\hline F14 & Inadequate contractor's experience & 1.16 & 5 & 0.04 & 25 & 0.83 & 14 \\
\hline F15 & $\begin{array}{l}\text { Claims and disputes with } \\
\text { stakeholders }\end{array}$ & 0.54 & 10 & 0.06 & 22 & 0.53 & 15 \\
\hline F24 & Political situation & 0.87 & 8 & 0.00 & 35 & 0.44 & 16 \\
\hline F22 & Land acquisition & 0.34 & 14 & 0.08 & 19 & 0.38 & 17 \\
\hline F23 & Weather & 0.38 & 12 & 0.04 & 25 & 0.35 & 19 \\
\hline F25 & Change orders due to the owner & 0.34 & 14 & 0.06 & 22 & 0.35 & 19 \\
\hline F16 & Shortage of labor & 0.01 & 40 & 0.48 & 13 & 0.34 & 20 \\
\hline
\end{tabular}

Table 4. Delay factors with more influence on road than building projects

\begin{tabular}{l|l|l|l}
\hline \multicolumn{4}{c}{ More influence on road projects than building projects } \\
\hline Delay factor & $\boldsymbol{I I}_{\boldsymbol{O}}$ & Delay factor & $\boldsymbol{I I}_{\boldsymbol{O}}$ \\
\hline Payment delays to contractor & 7.25 & Weather & 0.35 \\
Shortage of equipment & 1.58 & Inadequate bidding method & 0.15 \\
Claims and disputes with stakeholders & 0.53 & Project scope changes & 0.14 \\
Inadequate contractor's experience & 0.83 & Scope changes due to the owner & 0.13 \\
Political situation & 0.44 & & \\
\hline
\end{tabular}


Table 5. Delay factors with more influence on building than road projects

\begin{tabular}{|c|c|c|c|}
\hline \multicolumn{4}{|c|}{ More influence on building projects than road projects } \\
\hline Delay factor & $I I_{O}$ & Delay factor & $I_{O}$ \\
\hline Shortage of materials & 6.41 & Low productivity of labor & 0.93 \\
\hline Inadequate project planning & 5.44 & Shortage of labor & 0.34 \\
\hline Financial difficulties of contractor & 2.79 & $\begin{array}{l}\text { Late decision making by } \\
\text { consultants }\end{array}$ & 0.23 \\
\hline Failures in design & 1.33 & $\begin{array}{l}\text { Late approval of shop drawings } \\
\text { and sample materials }\end{array}$ & 0.18 \\
\hline Design changes & 1.09 & $\begin{array}{l}\text { Inadequate construction } \\
\text { methods }\end{array}$ & 0.14 \\
\hline Price variation of materials & 0.99 & & \\
\hline
\end{tabular}

Table 6. Delay factors with similar influence on road and building projects

\begin{tabular}{l|c|l|c}
\hline \multicolumn{4}{c}{ Similar influence on road and building projects $-I I_{O}$} \\
\hline Delay factor & $\boldsymbol{I I}_{\boldsymbol{O}}$ & Delay factor & $\boldsymbol{I I}_{\boldsymbol{O}}$ \\
\hline Financial difficulties of owner & 7.70 & Change orders due to the owner & 0.35 \\
Poor site management and & 3.15 & Poor site investigation & 0.23 \\
supervision & 1.78 & Unrealistic contract duration & 0.22 \\
Late decision making by owner & 1.76 & Delays of activities & 0.20 \\
Poor communication among & 0.38 & Delay of site mobilization & 0.11 \\
stakeholders & & & \\
Land acquisition &
\end{tabular}

Table 7. Spearman's rank correlation by project groups

\begin{tabular}{c|cccccc}
\hline & Road & Building & $\begin{array}{c}\text { Road } \\
\text { Africa }\end{array}$ & $\begin{array}{c}\text { Road } \\
\text { Asia }\end{array}$ & $\begin{array}{c}\text { Building } \\
\text { Africa }\end{array}$ & $\begin{array}{c}\text { Building } \\
\text { Asia }\end{array}$ \\
\hline Road & 1 & & & & & \\
Building & $0.385^{*}$ & 1 & & & & \\
Road - Africa & 0.530 & 0.530 & 1 & & & \\
Road - Asia & 0.704 & 0.069 & -0.111 & 1 & & \\
Building - Africa & 0.444 & 0.831 & 0.489 & 0.116 & 1 & 1 \\
Building - Asia & $0.345^{*}$ & 0.802 & $0.394^{*}$ & 0.152 & 0.431 & \\
\hline
\end{tabular}

* The correlation is significant at the 0.05 level (bilateral).

Table 7 shows the Spearman's rank correlation coefficients obtained for different groups according to the sample selected (see Table 1). The results show that the correlation between influences indices on road and building projects is moderate ( $\rho=0.385)$, which is evidence that there is moderate difference between delay factors on road and building projects. Related to Africa region, the correlation between delay factors on road and building projects $(\rho=0.489)$ is higher than the 
general correlation $(\rho=0.385)$ while in Asia region it is lower $(\rho=0.152)$, therefore, it is an indicator that delay factors differ from one region to another and one type of project to another.

A remarkable result, is the low correlation between road projects located in Africa and Asia $(\rho=-0.111)$ that is due to the different delay factors reported, within the sample of road projects from Africa, the factor "financial difficulties of owner" has a frequency of 6, while in Asian road projects it is not reported within the 10 most important factors, this is an indicator of financial problems of road project owners in some African countries unlike Asian countries. Other factor with considerable difference is "poor communication among stakeholders" in road projects from Asia region the frequency is 4 while in African road projects the factor is not reported in the top 10 factors. In the other side, the correlation between building projects from Africa and Asia is moderate $(\rho=0.431)$. These results are indicators that despite being projects of the same type some delay factors differ, phenomenon that could be related to different project locations.

\section{CONCLUSION}

The qualitative and quantitative analysis show that there are differences between delay factors in road and building projects. According to the influence index $(I I)$, the top 5 delay factors in road projects were: 1) payment delays to contractor, 2) financial difficulties of owner, 3) poor site management and supervision, 4) shortage of equipment and 5) inadequate contractor's experience. In building projects, the top 5 delay factors were: 1) shortage of materials, 2) inadequate project planning, 3) financial difficulties of owner, 4) financial difficulties of contractor and 5) payment delays to contractor. The findings show that delay factors with more influence on road than building projects are: payment delays to contractor, shortage of equipment, claims and disputes with stakeholders, inadequate contractor's experience, among others. Delay factors with more influence on building than road projects are: shortage of materials, inadequate project planning, financial difficulties of contractor, among others. Delay factors with similar influence on road and building projects are: financial difficulties of owner, poor site management and supervision, late decision making by owner, poor communication among stakeholders, among others.

The Spearman's rank correlation coefficient show that the correlation between delay factors on road and building projects is moderate $(\rho=0.385)$, which is evidence that there is a difference in the influence of the delay factors in road and building projects that could be associated to different project characteristics and other variables as the project location. Considering the qualitative and quantitative results, we recommend that future studies of delay factors be focused on one type of project and a particular geographical area, contrary to the majority of studies found that focus on construction projects in general.

The results presented are preliminary, we suggest new studies for a better characterization of the differences between delay factors in road and building projects, taking into consideration that the limitations of this study were: the lack of studies of delay factors of road and building projects in America, Europe and Oceania, and the use of the 10 most important factors reported and not a higher value. Future works could focus on: analyzing and explaining the differences in influence of 
the delay factors found in this study; others could be dedicated to studying the delay factors according to the geographical location of the project and others to compare delay factors among other project types.

\section{REFERENCES}

Abdellatif, H., \& Alshibani, A. (2019). "Major factors causing delay in the delivery of manufacturing and building projects in Saudi Arabia." Buildings, 9(4), 93. https://doi.org/10.3390/buildings 9040093

Aibinu, A. A., \& Odeyinka, H. A. (2006). "Construction delays and their causative factors in Nigeria." Journal of Construction Engineering and Management, 132(7), 667-677. https://doi.org/10.1061/(asce)0733-9364(2006)132:7(667)

Akogbe, R. K. T. M., Feng, X., \& Zhou, J. (2013). "Importance and ranking evaluation of delay factors for development construction projects in Benin." KSCE Journal of Civil Engineering, 17(6), 1213-1222. https://doi.org/10.1007/s12205-013-0446-2

Al-Hazim, N., Salem, Z. A., \& Ahmad, H. (2017). "Delay and cost overrun in infrastructure projects in Jordan." In Procedia Engineering (Vol. 182, pp. 1824). The Author(s). https://doi.org/10.1016/j.proeng.2017.03.105

Alaghbari, W., Kadir, M. R. A., Salim, A., \& Ernawati. (2007). "The significant factors causing delay of building construction projects in Malaysia." Engineering, Construction and Architectural Management, 14(2), 192-206. https://doi.org/10.1108/09699980710731308

Amoatey, C. T., Ameyaw, Y. A., Adaku, E., \& Famiyeh, S. (2015). "Analysing delay causes and effects in Ghanaian state housing construction projects." International Journal of Managing Projects in Business, 8(1), 198-214. https://doi.org/10.1108/IJMPB-04-2014-0035

Amoatey, C. T., \& Okanta, A. (2017). "Exploring critical road project delay factors in Ghana." Journal of Facilities Management, 15(2), 110-127. Retrieved from https://doi.org/10.1108/JFM-09-2016-0036

Aziz, R. F., \& Abdel-Hakam, A. A. (2016). "Exploring delay causes of road construction projects in Egypt." Alexandria Engineering Journal, 55(2), 15151539. https://doi.org/10.1016/j.aej.2016.03.006

Durdyev, S., Omarov, M., \& Ismail, S. (2017). "Causes of delay in residential construction projects in Cambodia." Cogent Engineering, 4(1), 1-12. https://doi.org/10.1080/23311916.2017.1291117

El-Razek, M. E. A., Bassioni, H. A., \& Mobarak, A. M. (2008). "Causes of delay in building construction projects in Egypt." Journal of Construction Engineering and Management, 134(11), 831-841. https://doi.org/10.1061/(ASCE)07339364(2008)134:11(831)

Famiyeh, S., Amoatey, C. T., \& Adaku, E. (2017). "Major causes of construction time and cost overruns." Journal of Engineering, Design and Technology, 15(2), 181-198. https://doi.org/10.1108/JEDT-11-2015-0075

Honrao, Y., \& Desai, D. (2015). "Study of delay in execution of infrastructure projects - highway construction." International Journal of Scientific and Research Publications, 5(6), 1-8. 
Kaliba, C., Muya, M., \& Mumba, K. (2009). "Cost escalation and schedule delays in road construction projects in Zambia." International Journal of Project Management, 27(5), 522-531. https://doi.org/10.1016/j.ijproman.2008.07.003

Kaming, P. F., Olomolaiye, P. O., Holt, G. D., \& Harris, F. C. (1997). "Factors influencing construction time and cost overruns on high-rise projects in Indonesia." Construction Management and Economics, 1(15), 83-94. https://doi.org/10.1080/014461997373132

Khair, K., Mohamed, Z., Mohammad, R., Farouk, H., \& Ahmed, M. A. (2017). "A management framework to reduce delays in road construction projects in Sudan." Arabian Journal for Science and Engineering. https://doi.org/10.1007/s13369-017-2806-6

Mahamid, I. (2017a). "Analysis of schedule deviations in road construction projects and the effects of project physical characteristics." Journal of Financial Management of Property and Construction, 22(2), 192-210. https://doi.org/10.1108/jfmpc-07-2016-0031

Mahamid, I. (2017b). "Schedule delay in Saudi Arabia road construction projects: size, estimate, determinants and effects." International Journal of Architecture, Engineering and Construction, 6(3), 51-58. https://doi.org/10.7492/IJAEC.2017.017

Mahamid, I., Bruland, A., \& Dmaidi, N. (2012). "Causes of delay in road construction projects." Journal of Management in Engineering, 28(3), 300-310. https://doi.org/10.1061/(asce)me.1943-5479.0000096

Omoregie, A., \& Radford, D. (2006). "Infrastructure delays and cost escalation: causes and effects in Nigeria." In Proceedings of the 6th International Postgraduate Research Conference in the Built and Human Environment (pp. 79-93). Delft University of Technology.

Patil, S., Gupta, A., Desa, D., \& Sajane, A. (2013). "Causes of delay in Indian transportation infrastructure projects." International Journal of Research in Engineering and Technology, 2(11), 71-80.

Rachid, Z., Toufik, B., \& Mohammed, B. (2018). "Causes of schedule delays in construction projects in Algeria." International Journal of Construction Management, 3599, 1-11. https://doi.org/10.1080/15623599.2018.1435234

Santoso, D., \& Soeng, S. (2016). "Analyzing delays of road construction projects in Cambodia: causes and effects." Journal of Management in Engineering, 32(6), 1-11. https://doi.org/10.1061/(ASCE)ME.1943-5479.0000467

Singh, S., Bala, A., Dixit, S., \& Varshney, D. (2018). "Critical analysis of causes of delay in residential construction projects in India." International Journal of Civil Engineering and Technology, 9(1), 330-345.

Sohu, S., Chandio, A. F., \& Keleemullah. (2019). "Identification of causes and minimization of delays in highway projects of Pakistan." Mehran University Research Journal of Engineering \& Technology, 38(1), 103-112.

Venkateswaran, C. B., \& Murugasan, R. (2017). "Time delay and cost overrun of road over bridge (ROB) construction projects in India." Journal of Construction in Developing Countries, 22(November), 79-96. https://doi.org/10.21315/jcdc2017.22.supp1.5 